\title{
A ERA DAS CARTAS: O DIÁRIO DA PROCURA DE COMPAGNON POR BARTHES
}

\author{
Dafne Di Sevo Rosa \\ Doutoranda em Letras pela Universidade Presbiteriana Mackenzie (UPM) \\ Professora da Universidade São Judas Tadeu (USJT) \\ dafne.rosa@yahoo.com.br
}

\section{RESENHA}

COMPAGNON, Antoine. A era das cartas. Belo Horizonte: Editora UFMG, 2019.

"Antoine Compagnon é professor de literatura francesa na Universidade de Columbia (Nova York) e no Collège de France". Assim é apresentado o autor de A era das cartas para aqueles que talvez não o conheçam e ao folhearem o livro e lerem sua sinopse se interessem pela narrativa. Entretanto, para aqueles que fazem parte do mundo das Letras e já se dedicaram ao estudo de $O$ demônio da teoria: literatura e senso comum (1999), Os cinco paradoxos da modernidade (2010), Os antimodernos (2011) ou Literatura para quê? (2012), a pequena biografia do autor, aparentemente dispensável, comove e se torna envolvente ao longo das 187 páginas da sua mais recente obra.

Em um livro que foge da crítica literária a qual comumente se dedica, Compagnon apresenta não só uma narrativa cuidadosamente desenvolvida como parte das inúmeras homenagens dedicadas ao centenário de nascimento de seu mestre e amigo Roland Barthes, ocorrido em 2015, como também apresenta ao leitor um olhar sincero e compreensivo de um renomado acadêmico para si mesmo no início de carreira.

Em um fluxo de consciência tanto determinado pela releitura de antigas cartas trocadas entre os dois personagens centrais da história (Compagnon e Barthes), como 
influenciado pela memória afetiva do narrador-personagem, a convivência entre o jovem aprendiz e seu mestre, nos fervilhantes anos de 1970, em Paris, se torna não só a tentativa de elaboração de um retrato de "um Barthes de carne e osso", como afirma Laura Taddei Brandini no revelador prefácio da edição brasileira da obra, como também se converte na descrição do percurso de um recém-formado engenheiro civil, paradoxalmente doutorando em Letras.

Nessa busca pela imagem humana do amigo e mestre morto há mais de 30 anos, Antoine revela não só situações de intimidade entre eles como também particularidades próprias de cada um, sem parecer desnecessariamente sentimental ou indelicado. Os dois personagens são descritos por meio de suas fraquezas, manias e inseguranças, o que torna o texto ainda mais informal e afetivo. Como se estivesse em uma conversa sobre um colega em comum, Compagnon envolve o leitor que se sente familiarizado também com as personalidades coadjuvantes da história e com a temática central discutida ao longo do relato.

Em ambientes descontraídos como cafés e restaurantes, frequentados pelos mais ilustres intelectuais franceses da época, como Michel Foucault e Jean Cayrol, tanto Compagnon como Barthes vão desenvolvendo projetos e concretizando ideias que consolidam seus nomes como críticos e teóricos da literatura. Concomitantemente também estreitam seus laços de respeito e admiração mútuos. A amizade entre os dois é o fio condutor da narrativa e permite que Compagnon aborde temas sigilosos da vida de cada um deles. Alguns desses temas são a depressão de Barthes, o particular relacionamento dele com sua mãe e sua própria morte.

Um dos personagens coadjuvantes mais marcantes no enredo é a mãe de Roland, superprotetora e extremamente cuidadosa, a senhora é presença constante na vida do 
filho e na casa frequentada por vários de seus amigos. Quando, em 1977, Henriette falece, Barthes, em seu processo de, parafraseando Compagnon, luta contra o luto, escreve notas que mais tarde dariam origem ao seu Journal de deuil (Diário de luto). O abatimento causado pela profunda tristeza após a perda da mãe, supostamente natural, é descrito por ele em uma das cartas e menosprezado pelo amigo que ao relê-la toma consciência da sua imaturidade diante do velado pedido de ajuda.

A depressão, fruto da abrupta interrupção de uma relação não só afetuosa como também de dependência, gera a apatia indiretamente provocadora do atropelamento fatal sofrido por Barthes em 1980. Nos últimos momentos entre os amigos, as lágrimas de despedidas retratadas no livro são de Barthes, mas não deixam de ser singelamente e simbolicamente compartilhadas com Compagnon e com os leitores mais sensíveis.

A empatia do leitor pela história narrada e por seus protagonistas é outro fator que contribui para a leitura ágil e descomplicada da trama. Saber das dificuldades encontradas por Antoine ao longo da escrita de sua tese, dos conflitos e da cumplicidade que compuseram sua orientação, descobrir a falta de produtividade que assombrava Barthes e as estratégias de elaboração de textos de cada um, aproxima essas duas grandes personalidades da crítica literária da realidade enfrentada por qualquer estudante de pós-graduação.

O conforto e a tranquilidade causados pela identificação entre o leitor e os personagens torna a leitura, em certos momentos, quase um aconselhamento para aqueles que trilham os caminhos da carreira acadêmica e buscam, se não serem membros de um importante colegiado, ao menos serem professores universitários.

Entre o célebre professor que o aceita como ouvinte em seu seminário e o amigo íntimo, Antoine demonstra como seu cotidiano é regularmente afetado pela relação com 
Barthes. Entre sonhos que tem com o amigo, entrevistas e palestras em que direta ou indiretamente comenta sobre o mestre, coincidências que o levam até um tapete bordado com as iniciais "R.B", o vocabulário carregado de expressões típicas do outro e a máquina de escrever usada por ambos, Compagnon se consolida como discípulo permanente de Barthes.

Os episódios envolvendo a Olivetti são alguns dos mais marcantes do enredo, pois, por um lado, confirmam toda a consideração do aprendiz pelo professor e, por outro lado, metaforicamente, atestam o reconhecimento da influência do mestre no percurso do estudante e a sua inevitável emancipação (mesmo que parcial ou incompleta). Tanto a importância da Olivetti para a narrativa, como o apreço de Compagnon pelo presente dado por Barthes e sua culpa por não o ter mais entre seus objetos pessoais, tornam o deslize cometido pelo editor dos exemplares publicados pela UFMG, ao incluir na capa uma Corona perceptível e indesculpável (Figura 1). No entanto, a edição de bolso comporta bem a narrativa intimista em que Antoine busca não só por Roland como por si mesmo, característica que torna o texto um fragmento autobiográfico melancólico, emotivo e de despretensiosa beleza.

Figura 1 - Capa do livro "A era das cartas", de Antoine Compagnon (Ed. UFMG)

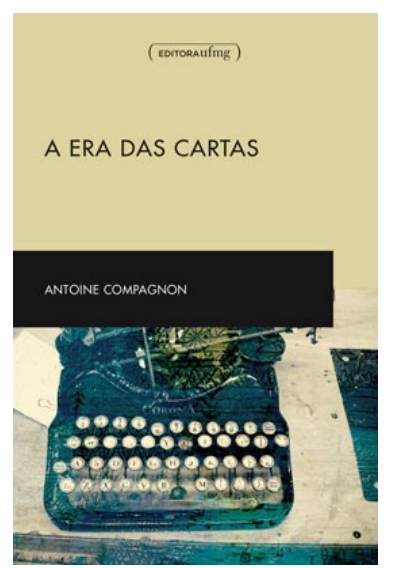

Fonte: Disponível em: <https://www.editora.ufmg.br/\#/pages/obra/710>. Acesso em: 25 jul. 2019. 
DOI: 10.12957/palimpsesto.2019.44196

Esse fragmento de discurso amoroso e cordial exemplifica dois vocábulos ausentes no estudo publicado por Roland Barthes, após o seminário em que Antoine Compagnon participou e no qual os dois tiveram a oportunidade de se aproximarem: Admiração e Amizade.

Recebido em 25 de julho de 2019. Aceite em 11 de novembro de 2019. 